\title{
THE ROLE OF DIGITAL ECONOMY AND DEVELOPMENT TRENDS IN ARMENIA
}

Voskanyan Gohar Vazgen, Ph.D. in economics, Scientific researcher, assistant, M. Kotanyan Institute of Economics of the NAS RA, Armenian National Agrarian University, Yerevan, Republic of Armenia

\section{DOI: https://doi.org/10.31435/rsglobal_conf/30082021/7649}

Abstract. The purpose of the article is to present the essence and significance of the digital economy, to analyze the work done in the field of digital economy in the Republic of Armenia, to present clear proposals for the development of the digital economy in the Republic of Armenia. In order to achieve the set goal, the article presented the researches of Armenian and foreign authors on digital economy, the positive-negative sides of digital economy, the work carried out in the field of digital economy, as well as a number of problems hindering the development of digital economy in Armenia. As a result of the studies and analyzes, clear recommendations were presented, the application of which will contribute to the development of the digital economy in the Republic of Armenia.

Keywords: digital economy, technologies, IT sector, database, strategy, barriers.

Introduction. Digitalization is one of the strongest trends that are changing the global economy today. The era of digitalization is slowly and surely, and at the same time inevitably changing the face of the industry, the structure of economies, and the whole way of life and thinking ${ }^{1}$.

The digital economy is a recently-emerging phenomenon of increasing importance given estimates of double-digit annual growth around the world, with particularly strong growth in the global South. The driving forces behind this emergence are economic and political, but they of course also have roots in technological innovation (itself shaped by wider forces). In the 1990s, economic changes were associated mainly with emergence of the Internet, and this remains a foundation for growth of the digital economy. But during the 2000s and 2010s a succession of new information and communication technologies (ICTs) has diffused and underpinned economic change. This includes the embedding of connected sensors into more and more objects (the Internet of things); new end-user devices (mobile phones, smartphones, tablets, netbooks, laptops, 3D printers); new digital models (cloud computing, digital platforms, digital services); growing intensity of data usage through spread of big data, data analytics and algorithmic decision-making; and new automation and robotics technologies ${ }^{2}$.

Purpose of the research. The purpose of the article is to present the essence and significance of the digital economy, to analyze the work done in the field of digital economy in the Republic of Armenia, to present clear proposals for the development of the digital economy in the Republic of Armenia.

Methodology. Analytical-comparative methods were used during the research. In particular, the works of Armenian and foreign researchers on the digital economy were studied, as well as the results of analyzes conducted by international organizations. In 2018, the World Bank delivered a report - Digital Dividends on the state of the digital economy. Benefits and risks of its development were identified. According to the experts, benefits of the digital economy are as follows: labor productivity growth; enhanced competitiveness; reduction of production costs; capitalization growth; new jobs; new markets; satisfaction of human needs; improved living standards; a lower level of poverty and social inequality. Possible risks are as follows: cybersecurity; massive unemployment; a digital boundary between citizens and businesses and between countries. The main advantages of digitalization of business processes are as follows:

\footnotetext{
${ }^{1}$ Alibekova G. and others, Digital Transformation Enablers and Barriers in the Economy of Kazakhstan, Journal of Asian Finance, Economics and Business Vol 7 No 7 (2020), p. 565 - 575. Retrieved from https://www.researchgate.net/publication/343190082_Digital_Transformation_Enablers_and_Barriers_in_the_E conomy_of_Kazakhstan

2 RUMANA BUKHT \& RICHARD HEEKS, Defining, Conceptualising and Measuring the Digital Economy, Development Informatics, Working Paper Series, Paper No. 6, p. 2.
} 
- reduced costs of services and new sources of income (online services are cheaper than traditional ones);

- accelerated access to the global market (goods and services reach the market quickly and become accessible to people around the world);

- products and services can be instantly improved to meet new expectations or needs;

- conditions for the diverse informational, educational, scientific content are created faster. They are better and more convenient;

- unification of efforts (Internet sites) for creating businesses, searching for employees, partners, resources and sales markets;

- increased productivity and innovations (improved market supply meeting demand and growing needs of consumers. - Intellect stimulates and supports the accelerated economic development).

Heads of national companies understand that digital technologies help them compete in the domestic or foreign markets. However, companies are very pragmatic ${ }^{1}$.

In recent years, various researchers and organizations have frequently studied and discussed the impact of digitalization on the economy. They try to identify the link between digitalization and productivity, digitalization and employment, develop a policy aimed at improving the sector. There are three main ways to evaluate a digital economy:

$>$ the productive method that measures the production of goods and services in the sector;

$>$ Income method, which measures the income of individuals and enterprises in the industry;

$>$ Expenditure method that measures the consumption of finished goods by households, businesses, government and non-residents ${ }^{2}$.

Research results. The digitalization of the economy is of vital importance for Armenia. Information is one of the "products" which use and production can give great strength and impetus to the country's economy, regardless of economic and geographical barriers. It enables organizations to operate globally. That is why the sphere of information technologies has been declared by the Government of the Republic of Armenia as a priority branch of the economy ${ }^{3}$.

The Ministry of High Technological Industry, which was established in 2018, has an important role in the process of digitalization of the Republic of Armenia. The goal of the Ministry is to create and strengthen conditions for balanced and sustainable development of high technologies, digitalization, cyber security, innovative technologies, communication, internet, as well as economic growth of the state ${ }^{4}$.

In 2019, the Digitalization Council was formed in Armenia, the activity of which aims to ensure the digitalization of the public administration system, the economy, the promotion of digital skills, as well as the harmonization of the work of state agencies in the field of digitalization ${ }^{5}$.

In 2020, the Government of the Republic of Armenia approved the digitalization strategy, which is a comprehensive development plan targeting the complete development of the country, covering all socio-economic spheres. It is built on three main, strategic pillars:

1) Public administration,

2) Economy,

3) Society.

The development of high technologies has a decisive role in increasing the competitiveness, security and living standards of the state. The states that create and develop high technologies, register changes in the competitive field, occupy leading positions in the international arena. Armenia's digitalization strategy aims to ensure the digital transformation of government, economy and society, with a particular focus on:

\footnotetext{
${ }^{1}$ L G Nikityuk, L T Tkachuk, G K Korotkova, The Role of the Digital Economy in Developing the Market Model of Russian Society, Advances in Economics, Business and Management Research, volume 128, International Scientific Conference "Far East Con" (ISCFEC 2020), p.380-382.

${ }^{2}$ Sargsyan H. and others, The Problems of Forming the Institutional System of Digital Transformations of the RA Economy, Yerevan, 2020.- 160 p., p. 36-46.

3 Sedrakyan T., Models of Strategic Development of the Digital Economy of the Republic of Armenia, Dissertation, Yerevan, 2016, 114 p., p. 3.

${ }^{4}$ Decision of the Prime Minister of the Republic of Armenia on approving the charter of the Ministry of HighTech Industry of the Republic of Armenia, June 11, 2018 N 698-L, Retrieved from https://www.arlis.am/documentView.aspx?docid=131190

${ }^{5}$ Decision of the Prime Minister of the Republic of Armenia, October 15, 2019 N 1472-A, Retrieved from https://www.arlis.am/DocumentView.aspx?docid=135538
} 
1. Efficient, fast, transparent and data-driven public administration;

2. Modernization of the private sector of the economy and increasing competitiveness through digital platforms and smart solutions,

3. Creating a workforce that has digital skills, that is ready for the economy of the future, as well as the widespread use of digital solutions by the public ${ }^{1}$ :

The website www.e-gove.am is being created to digitize public administration. The purpose of the site is to combine all the e-government tools and data resources of the state agencies of the Republic of Armenia and to create a comfortable environment for their use ${ }^{2}$.

The basis of the digital economy is the database. In order to have a solid information base for research, it is very important to keep statistics in this or another field based on international standards. Internationally compatible statistical measurements are not yet widespread in the developing world, which is why internal studies are based on indexes developed by international organizations. The indicators calculated by the RA Statistical Service and other organizations are quite limited, they give a very narrow opportunity for analysis. Below are a number of issues related to the statistics of the field.

1. Decentralization,

2. Irregularity,

3. Lack of periodicals,

4. Non-compliance with international standards,

5. Lack of awareness of international organizations in the field of high technologies in Armenia:

6. Lack of information on other areas of technology other than ICT.

Among the problems that need to be solved is the fact that some ranking indexes related to the technological development of the Republic of Armenia are calculated by large international research organizations, but this information is not available (usually it is paid). Besides, no official source in Armenia publishes even the results of analyzes made by those international organizations for Armenia. Nevertheless, the data and calculations collected by the largest international organizations allow us to assess the development of the technological, telecommunication and development sectors of the Republic of Armenia in the overall development of economic growth ${ }^{3}$ :

In Armenia $96 \%$ of households and $86 \%$ of small and medium enterprises (SMEs) have internet connection. However, there are some interesting differences in the way individuals use the Internet. As data show there is still a huge untapped market for online services, that many people and businesses are not realizing their digital capabilities ${ }^{4}$.

Significant progress has been made since the IT sector was declared a priority. However, there are many problems that companies in this field face. In particular, as a result of the research, it became clear that there are especially problems with the lack of highly qualified labor force, tax-customs procedures, access to financial resources, and access to the international market ${ }^{5}$.

Conclusions. The conducted studies show that active works are being carried out in the direction of digitalization in the Republic of Armenia. Legislative acts have been developed, certain infrastructures, electronic platforms, etc. have been created. At the same time, the discovery of some circumstances hindering the development of the digital economy provides a basis for fulfilling the following recommendations for the development of the digital economy in the Republic of Armenia.

1. Create a unified, comprehensive and reliable database on all areas, which will allow using the capabilities of digital technologies even more effectively.

2. Organize information courses for the population, as well as for business representatives, which will enable them to use online services even more.

3. Eliminate factors hindering the development of the IT sector in Armenia, which will contribute to an even more efficient organization of the digital economy.

4. In order to solve the above-mentioned problems, it is necessary to establish close cooperation between all participants in the digital economy (population, state and business representatives).

\footnotetext{
${ }^{1}$ Armenia's Digitalization Strategy 2020-2025, 2020, pp. 13-14.

${ }^{2}$ Retrieved from https://www.e-gov.am/

${ }^{3}$ Technological development and digital economy / Vardan Sargsyan and others. - Yerevan, 2014 - 124 p., p. 10-13.

${ }^{4}$ Retrieved from https://blogs.worldbank.org/hy/europeandcentralasia/interneti-ogtagorcowme-hayastanowmdepi-tvayin-mijotsneri-aveli-mec

${ }^{5}$ Retrieved from https://asue.am/amberd/publication/analytics/it-sector-achievements-and-problems
} 


\section{REFERENCES}

1. Alibekova G. and others, Digital Transformation Enablers and Barriers in the Economy of Kazakhstan, Journal of Asian Finance, Economics and Business Vol 7 No 7 (2020), p. 565 - 575 Retrieved from https://www.researchgate.net/publication/343190082_Digital_Transformation_Enablers_and_Barriers_in_t he_Economy_of_Kazakhstan

2. RUMANA BUKHT \& RICHARD HEEKS, Defining, Conceptualising and Measuring the Digital Economy, Development Informatics, Working Paper Series, Paper No. 6, p. 2.

3. L G Nikityuk, L T Tkachuk, G K Korotkova, The Role of the Digital Economy in Developing the Market Model of Russian Society, Advances in Economics, Business and Management Research, volume 128, International Scientific Conference "Far East Con" (ISCFEC 2020), p.380-382.

4. Sargsyan H. and others, The Problems of Forming the Institutional System of Digital Transformations of the RA Economy, Yerevan, 2020.- 160 p., p. 36-46.

5. Sedrakyan T., Models of Strategic Development of the Digital Economy of the Republic of Armenia, Dissertation, Yerevan, 2016, 114 p., p. 3.

6. Decision of the Prime Minister of the Republic of Armenia on approving the charter of the Ministry of High-Tech Industry of the Republic of Armenia, June 11, 2018 N 698-L, Retrieved from https://www.arlis.am/documentView.aspx?docid=131190

7. Decision of the Prime Minister of the Republic of Armenia, October 15, 2019 N 1472-A, Retrieved from https://www.arlis.am/DocumentView.aspx?docid=135538

8. Armenia's Digitalization Strategy 2020-2025, 2020, pp. 13-14.

9. Retrieved from https://www.e-gov.am/

10. Technological development and digital economy / Vardan Sargsyan and others. - Yerevan, 2014 - 124 p., p. 10-13.

11. Retrieved from https://blogs.worldbank.org/hy/europeandcentralasia/interneti-ogtagorcowmehayastanowm-depi-tvayin-mijotsneri-aveli-mec

12. Retrieved from https://asue.am/amberd/publication/analytics/it-sector-achievements-and-problems 